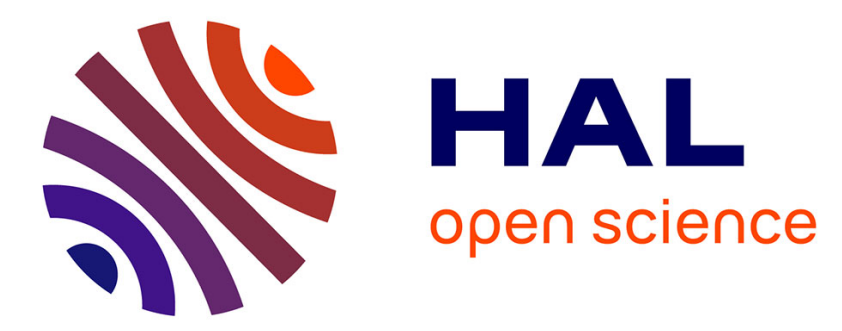

\title{
EXPERIMENTAL STUDIES OF SOLUBILITY OF ELEMENTAL SULPHUR IN SUPERCRITICAL CARBON DIOXIDE
}

Sophie Jay, Pierre Cézac, Jean-Paul Serin, Jacques Mercadier, Cédric Arrabie, Jean-Marc Legros-Adrian

\section{To cite this version:}

Sophie Jay, Pierre Cézac, Jean-Paul Serin, Jacques Mercadier, Cédric Arrabie, et al.. EXPERIMENTAL STUDIES OF SOLUBILITY OF ELEMENTAL SULPHUR IN SUPERCRITICAL CARBON DIOXIDE. 9th International Symposium on SuperCritical Fluids, François Cansell (ICMCB - Bordeaux); Jacques Fages (RAPSODEE - Albi); Jacques Mercadier (LATEP - Pau), May 2009, Arcachon, France. hal-02194158

\section{HAL Id: hal-02194158 https://hal-univ-pau.archives-ouvertes.fr/hal-02194158}

Submitted on 25 Jul 2019

HAL is a multi-disciplinary open access archive for the deposit and dissemination of scientific research documents, whether they are published or not. The documents may come from teaching and research institutions in France or abroad, or from public or private research centers.
L'archive ouverte pluridisciplinaire HAL, est destinée au dépôt et à la diffusion de documents scientifiques de niveau recherche, publiés ou non, émanant des établissements d'enseignement et de recherche français ou étrangers, des laboratoires publics ou privés. 


\title{
EXPERIMENTAL STUDIES OF SOLUBILITY OF ELEMENTAL SULPHUR IN SUPERCRITICAL CARBON DIOXIDE
}

\author{
Sophie Jay ${ }^{\text {a }}$, Pierre Cézac ${ }^{\text {a* }}$, Jean-Paul Serin ${ }^{\text {a }}$, Jacques Mercadier ${ }^{\text {a }}$, \\ Cédric Arrabie ${ }^{\mathrm{b}}$, Jean-Marc Legros-Adrian ${ }^{\mathrm{b}}$ \\ ${ }^{a}$ High Pressure Processes Group -Dep. Chemical Engineering, Laboratoire de Thermique, Energétique et Procédés \\ (LaTEP), Université de Pau et des Pays de l'Adour, rue Jules Ferry, BP 7511 Pau Cedex, France. \\ ${ }^{\mathrm{b}}$ Ecole Nationale Supérieure en Génie des Technologies Industrielles, rue Jules Ferry, BP 7511 Pau Cedex, France
}

\section{INTRODUCTION}

It is well known that elemental sulphur deposition is a serious problem troubling the production of sour natural gas. This deposit can also occur during transport. In the transport network, natural gas is transported at an average pressure of $5 \mathrm{MPa}$. However, to enter the distribution network, the gas pressure has to be reduced to $0.5 \mathrm{MPa}$. Consequently, a solid sulphur accumulation can occur just behind the gas expander. This solid deposit leads to a sealing problem, which regularly compromises the operation of the station. One of the hypotheses proposed to explain the solid accumulation and based on a thermodynamic approach [1] is the desublimation of sulphur. Indeed, during gas expansion, the pressure and the temperature both decrease. Consequently, the gas may become over saturated in sulphur. Because we are below the temperature of the triple point of sulphur, part of the gaseous sulphur can be transformed into solid particles. Thus, it is important to obtain the solubility data of sulphur in natural gases under $373.15 \mathrm{~K}$ and $20 \mathrm{MPa}$. The first step is to determine its solubility in the major gases, which constitute natural gas like $\mathrm{CO}_{2}$ or $\mathrm{CH}_{4}$.

Several authors measured the solubility of sulphur in pure gases, as well as in synthetic gas with composition approaching natural gas. The experiments were all carried out under conditions of temperature and pressure comparable to the conditions of field. Six groups of authors studied the solid-gas sulphur equilibrium, and determined the solubility of sulphur in natural gas Table 1 summarizes for each paper the nature of the gas considered, the ranges of pressure and temperature conditions for measuring the solubility of sulphur and the volume of the reactor used for the saturation.

Five groups of authors ([2], [4], [5], [6] and [7]) studied binary, ternary and gas mixtures of composition close to gas field composition. Kennedy and Wieland [2], Roof [3] and Gu \& al. [6] studied solubility of sulphur in hydrogen sulphide. Only Kennedy and Wieland [2] and Gu $\&$ al. [6] studied solubility of sulphur in pure gases as carbon dioxide and methane, major gases in the transport network.

Kennedy and Wieland [2] studied solubility of sulphur in $\mathrm{CO}_{2}$ and $\mathrm{CH}_{4}$ in a temperature range from $338.71 \mathrm{~K}$ to $394.26 \mathrm{~K}$ and pressure from $6.89 \mathrm{MPa}$ to $41.35 \mathrm{MPa}$. The equilibrium is established in a sulphur equilibrium bomb, which contained $18 \mathrm{~cm}^{3}$ of elemental sulphur, maintained at the desired temperature and pressure. Equilibrium time and presence of an agitation device are not reported. The saturated gas was expanded to atmospheric pressure, and the precipitated sulphur was quantified with the ASTM Lamp Sulphur Method that consists in burning completely the sulphur trapped in glass wool, and in analyzing the products of combustion neutralized and trapped in an absorber.

\footnotetext{
*Corresponding author. fax: +33 5 59407801. E-mail address: pierre.cezac@univ-pau.fr
} 
$\mathrm{Gu} \&$ al. [6] reported the solubility data of sulphur in pure $\mathrm{CO}_{2}$ and $\mathrm{CH}_{4}$, with temperatures of $363.2 \mathrm{~K}$ and $383.2 \mathrm{~K}$ and pressures ranged from $12.07 \mathrm{MPa}$ to $40.52 \mathrm{MPa}$ for $\mathrm{CO}_{2}$, and at 383.2 $\mathrm{K}$ and pressures ranged from $20.52 \mathrm{MPa}$ to $50.17 \mathrm{MPa}$ for $\mathrm{CH}_{4}$. The experimental apparatus was composed of an $\mathrm{H}_{2} \mathrm{~S}$-resistant stainless steel equilibrium cell with a piston where solid sulphur and gas contacted to establish solid-gas equilibrium. This reactor stirred by a rocking device during 20 hours was immersed in an oil bath to maintain constant temperature. A sample of saturated gas was withdrawn from the cell and flashed through a valve in a sampling tube, while the pressure in the reactor was held constant with the piston. Then, the tubing was dismantled and rinsed with $100 \mathrm{~cm}^{3}$ of carbon disulfide to dissolve the sulphur collected. $\mathrm{CS}_{2}$ was evaporated off under atmospheric pressure, and the sulphur was weighed.

\begin{tabular}{|c|c|c|c|c|}
\hline & Gas composition & $\begin{array}{c}\text { Range of } \\
\text { temperature }(K)\end{array}$ & $\begin{array}{c}\text { Range of } \\
\text { pressure (MPa) }\end{array}$ & $\begin{array}{c}\text { Volume of } \\
\text { reactor }\left(\mathrm{cm}^{3}\right)\end{array}$ \\
\hline $\begin{array}{c}\text { Kennedy and Wieland } \\
\text { (1960) [2] }\end{array}$ & $\begin{array}{l}\text { Pure } \mathrm{CH}_{4}, \mathrm{CO}_{2} \text { and } \mathrm{H}_{2} \mathrm{~S} \\
\text { Binary and ternary }\end{array}$ & 338.71 to 394.26 & 6.89 to 41.35 & Not specified \\
\hline $\operatorname{Roof}(1971)[3]$ & $\begin{array}{l}\mathrm{H}_{2} \mathrm{~S} \\
\mathrm{CS}_{2}\end{array}$ & $\begin{array}{c}316.48 \text { to } 383.15 \\
338.71\end{array}$ & $\begin{array}{l}7 \text { to } 31.15 \\
7 \text { to } 34.6\end{array}$ & 355 \\
\hline $\begin{array}{l}\text { Brunner and Woll } \\
\text { (1980) [4] }\end{array}$ & $\begin{array}{l}\mathrm{H}_{2} \mathrm{~S} \\
\mathrm{CH}_{4}-\mathrm{H}_{2} \mathrm{~S}-\mathrm{CO}_{2}-\mathrm{N}_{2}\end{array}$ & 373.15 to 433.15 & 10 to 60 & 400 \\
\hline $\begin{array}{c}\text { Brunner, Place and Woll } \\
\text { (1988) [5] }\end{array}$ & $\begin{array}{l}\mathrm{CH}_{4}-\mathrm{H}_{2} \mathrm{~S}-\mathrm{CO}_{2}-\mathrm{N}_{2}- \\
\mathrm{C}_{2} \mathrm{H}_{6}-\mathrm{C}_{4} \mathrm{H}_{10} \\
\text { Gas field composition }\end{array}$ & 388 to 408 & $\begin{array}{l}6.7 \text { to } 155 \\
7 \text { to } 43\end{array}$ & $\begin{array}{l}30,110 \text { and } \\
550\end{array}$ \\
\hline Gu \& al. (1993) [6] & $\begin{array}{l}\text { Pure } \mathrm{CH}_{4}, \mathrm{CO}_{2} \text { and } \mathrm{H}_{2} \mathrm{~S} \\
\text { Gas field composition }\end{array}$ & $\begin{array}{c}363.2 \text { to } 383.2 \\
363.2\end{array}$ & $\begin{array}{l}11.83 \text { to } 50.17 \\
11.47 \text { to } 34.71\end{array}$ & 300 \\
\hline Sun and Chen (2003) [7] & $\mathrm{CH}_{4}-\mathrm{H}_{2} \mathrm{~S}-\mathrm{CO}_{2}$ & 303.2 to 363.2 & 20 to 45 & 300 \\
\hline
\end{tabular}

Table 1 : Summary of previous studies obtained between 1960 and 2003

The reported experimental data on the solubility of sulphur in pure major gases are far from sufficient and are in too high ranges of temperature and pressure to explain and to avoid the solid sulphur accumulation in the transport network. In this paper, solubility of elemental sulphur was measured in $\mathrm{CO}_{2}$, with temperatures ranged from $333.15 \mathrm{~K}$ to $363.15 \mathrm{~K}$ and pressures up to $30 \mathrm{MPa}$.

\section{MATERIALS AND METHOD}

\section{$\underline{\text { APPARATUS }}$}

The experimental apparatus shown in Figure 1 is a special design developed with Top Industrie S.A., company specializing in high pressure technology, research and design prototypes.

A stainless steel equilibrium cell where solid sulphur and $\mathrm{CO} 2$ contacted and established the solid-gas equilibrium is the first key of the apparatus. The equilibrium cell has a maximum working space of $500 \mathrm{~cm} 3$ and a maximum working pressure of $50 \mathrm{MPa}$ and is equipped with a stirrer. Pure gas is introduced into the equilibrium cell using a gas booster. Another booster brings nitrogen to high pressure, and then a piston ensures the pressure regulation. A heating 
band allows to reach the desired temperature in the equilibrium cell. Other parts of the apparatus include valves, manometers, pressure sensor, thermocouple, bursting discs, etc. The second key is the trapping of gaseous sulphur. A flash is made through a valve: the saturated gas was expanded to atmospheric pressure while the pressure of the equilibrium cell was held constant tanks to the piston. The saturated gas flows through two $5 \mu \mathrm{m}$ filters which trap a certain amount of solid sulphur. After, the gas bubbles into two stainless steel bottles filled with a trapping mixture. The last key is the analysis of the elemental sulphur trapped. Gas volume sampled is measured with a mass flow meter.

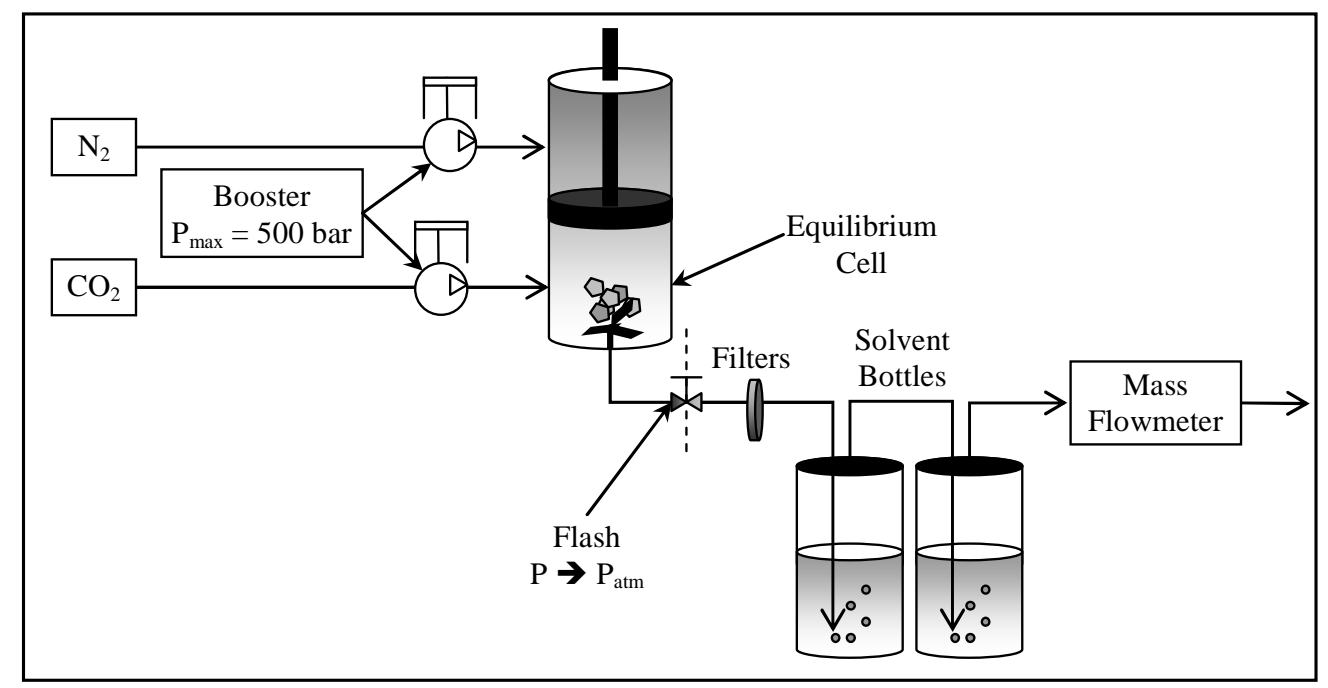

Figure 1: Apparatus for measurement of solubility of sulphur

\section{MATERIALS}

Chemicals. Sulfur is a high-purity finely dispersed solid distributed by Merck with a content of (99.0 to 100.0) \%.Triphenylphosphine (TPP), triphenylphosphine sulfide (TPPS) and triphenylphosphate $\left(\mathrm{TPPO}_{4}\right)$ are Merck's products for synthesis and are $99 \%$ pure each. Toluene (purity > $99.8 \%$ ) is obtained from Fisher Bioblock Scientific. Ethanol (purity > 99.5 $\%)$ is obtained from Merck.

Gases used are supplied by Air Liquide. For the pilot of saturation, Nitrogen used is an industrial gas, and Carbon Dioxide is $99 \%$ pure. For chromatography, Helium used has a stated purity of more than $99.999 \%$ and Hydrogen is $99.995 \%$ pure. A mixture of $80 \%$ of nitrogen and $20 \%$ of oxygen is used to ignite the flame of the chromatograph detector.

Gas Chromatography. Samples are analyzed on a ThermoFisher Scientific Trace GC Ultra $^{\mathrm{TM}}$ gas chromatograph coupled with a flame photometric detector (FPD), which is specific for sulfur and phosphorus. Because TPPS contains a phosphorus atom, the FPD is used in phosphorus mode with a $560 \mathrm{~nm}$ interference filter and a base at $593.15 \mathrm{~K}$. Helium is used as carrier gas at a column flow rate of $8.33 \cdot 10^{-2} \mathrm{~cm}^{3} \cdot \mathrm{s}^{-1}$, the Split/Splitless Injector is operated at $573.15 \mathrm{~K}$ with a split ratio of 10 . A TR-5 Trace GC Capillary Column with a $0.53 \mathrm{~mm}$ internal diameter, a $1 \mu \mathrm{m}$ thick film, and a length of $30 \mathrm{~m}$ is used in isotherm mode at $563.15 \mathrm{~K}$.

\section{EXPERIMENTAL PROCEDURE}


Saturation of gas in sulphur. Before closing the equilibrium cell, approximately $5 \mathrm{~g}$ of sulphur is added to it. The equilibrium cell, connected to gas cylinders, is filled with $\mathrm{CO}_{2}$. The reactor is isolated from the rest of the apparatus, the heating band reaches the desired temperature and the stirrer establishes equilibrium between each phase. The pure gas and the solid sulphur are stirred for 15 hours to establish gas-solid equilibrium.

Flash. After equilibrium has been reached, the saturated gas is expanded to atmospheric pressure. During this step, the cell pressure is kept constant thanks to the piston. The sampling speed is controlled to be very slow to ensure maximum of sulphur deposition in filters. Then, the gas bubbles into a trapping mixture in which sulphur reacts in solution, and leave the system cleaned of sulphur. This trapping mixture is analysed by gas chromatography. The total volume of the gas withdrawn is measured using a gas meter, and then revised to standard condition.

Analysis. Filters are drying in oven at $333.15 \mathrm{~K}$, and the amount of sulphur contained in filters is firstly determined by weighing with an electronic precision scale. Then, filters are dismantled and rinsed with trapping solution to dissolve the sulphur deposited and make it react. The CPG analyse of this solution ensure to get more precision. The solubility of sulphur is then calculated from the knowledge of the amount of sulphur recovered in tubing and in the two bottles, and from the knowledge of the volume of gas measured.

Principle of the Gas Chromatography Analysis. The chemical reaction developed by Bartlett and Mergurian [8] is the basis of the analytical method used in this paper. This reaction between elemental sulphur and triphenylphosphine (TPP), shown in Figure 2, leads to the formation of sulfur triphenylphosphine.

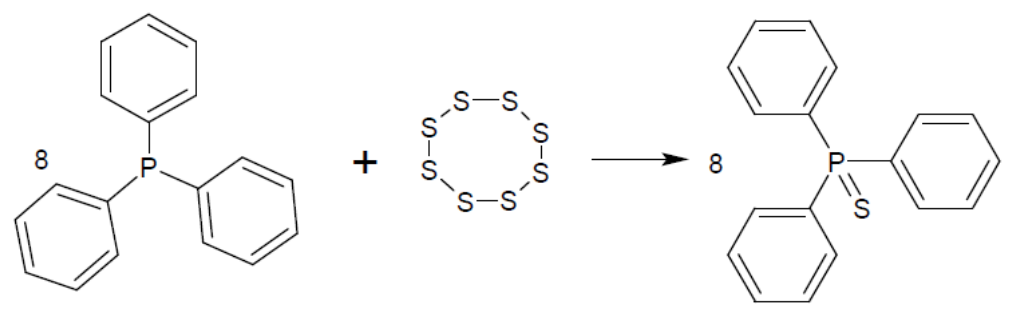

Figure 2: Chemical reaction between elemental sulphur $\left(\mathbf{S}_{8}\right)$ and triphenylphosphine (TPP)

So, the trapping mixture is initially constituted of toluene and an excess of triphenylphosphine (TPP). To significantly increase the efficiency of the reaction, a quantity four times higher than the stoichiometric conditions is fixed. Clark and Lesage [9] indicated that toluene was a good solvent for this reaction. Moreover, the choice of toluene as solvent has the advantage of being the same as the one chosen to clean pieces affected by sulphur deposits. When a sample of saturated gas flows through the trapping mixture, sulphur comes into contact with TPP and reacts completely in order to form triphenylphosphine sulphide (TPPS). At the end of the experiment, the analytical method developed by Lesage and Clark [9] and Davis et al. [10] is use to quantify the solution.

The product of the reaction (TPPS) is volatile and thermally stable enough to be quantified using gas chromatography. Concentration of internal standard $\mathrm{TPPO}_{4}$ is fixed at $1.5 \mathrm{mg} \cdot \mathrm{dm}^{-3}$. A typical chromatogram is presented in Figure 3. The four peaks generated by this analysis represent the unreacted TPP introduced in excess in the trapping solution, the internal standard $\mathrm{TPPO}_{4}$ with a known concentration, the triphenyloxide (TPPO) formed by oxidation of TPP, and the product of the reaction TPPS. To ensure maximum cleanliness of the syringe, 
it is flushed at least 60 times with toluene and ethanol. Pure toluene is injected to verify the cleanliness of the syringe. Each injection sample is repeated 5 times.

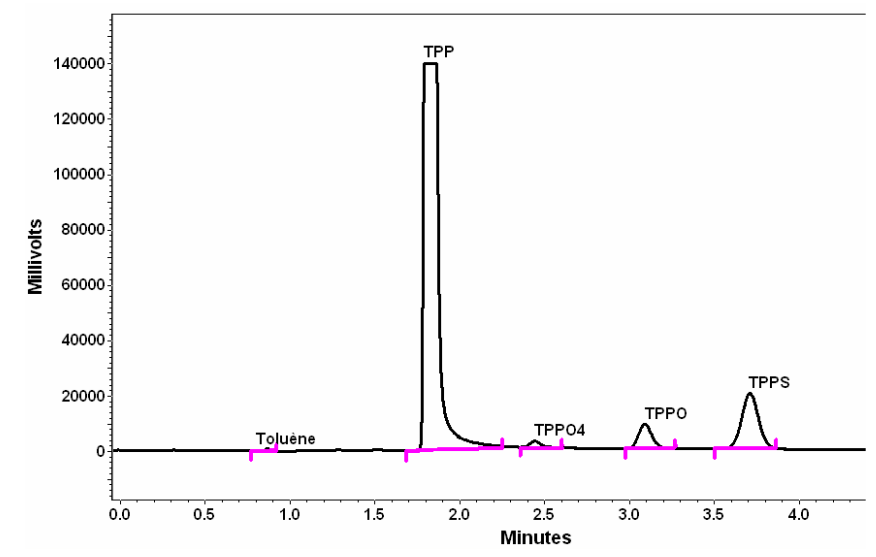

Figure 3: Order of elution and time of retention for each species in solution

\section{RESULTS AND DISCUSSIONS}

Validation of Analytical Method. First, we validated the analytical method of sulphur quantification. Samples of known concentration in sulphur are prepared. A mass of solid sulphur is weighed accurately, and non-saturated solutions are obtained by successive dilutions. TPP and $\mathrm{TPPO}_{4}$ are introduced in the last diluted solution, and this one is injected in the chromatograph. The quantity of sulphur contained in the solution is determined by analytical method, and this result is compared with the known value. A deviation of $0.7 \%$ between the theoretical weighted value and the value obtained by chromatographic analysis demonstrates the accuracy of the chromatographic method used.

A relative standard deviation consistently below $4 \%$ is found for each analysis.

Results. Data of sulphur solubility in $\mathrm{CO}_{2}$ up to $300 \mathrm{MPa}$, and for $333.15 \mathrm{~K}$ and 363.15 $\mathrm{K}$ have been assembled up to now. The solubility data for these two temperatures, and depending on the pressure, are given in Figure 4 for $333.15 \mathrm{~K}$ and in Figure 5 for $363.15 \mathrm{~K}$.

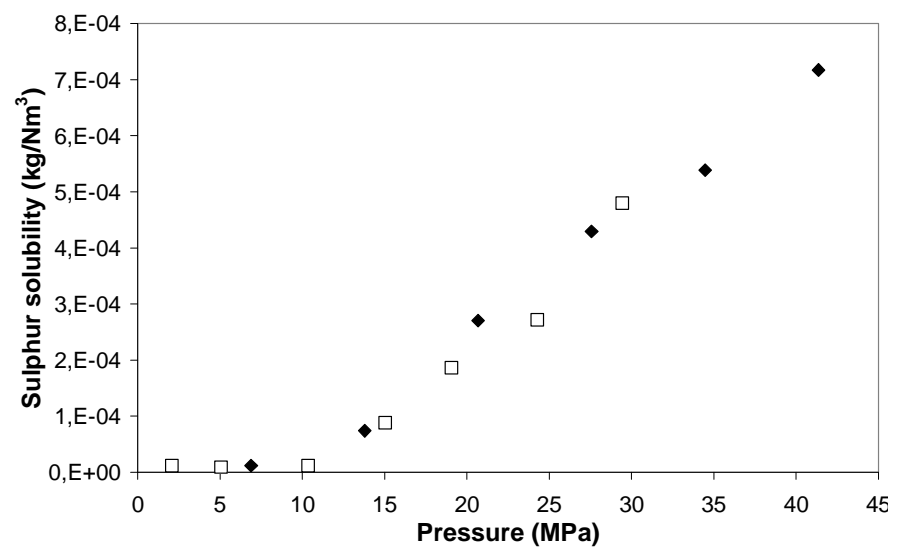

Figure 4: Isothermal solubility of sulphur to $333.15 \mathrm{~K}$ depending on the pressure evolution. $\square$ experimental data of this work; ef. [2] 


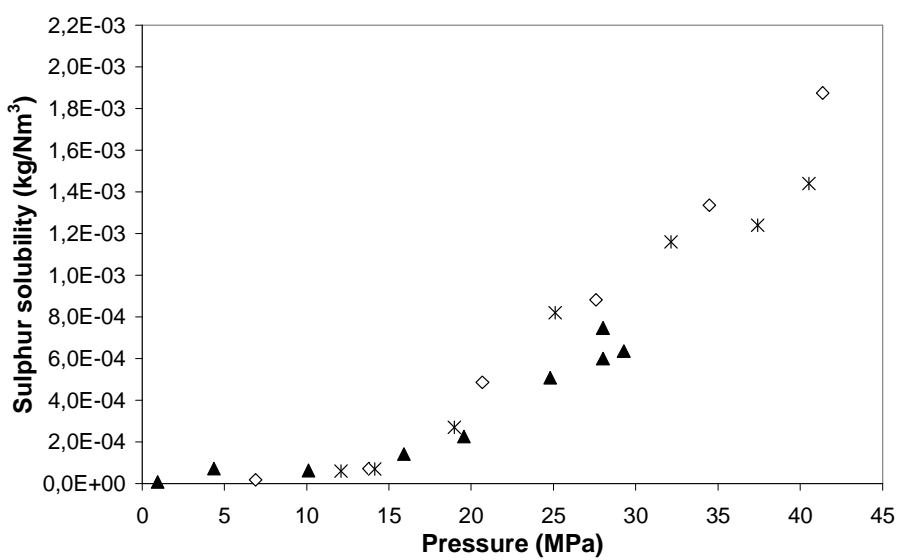

Figure 5: Isothermal solubility of sulphur to $363.15 \mathrm{~K}$ depending on the pressure evolution. $\boldsymbol{\Delta}$, experimental data of this work; $\diamond$, ref. [2]; $*$, ref. [6]

\section{CONCLUSION}

The experimental apparatus used in this work was validated: new data for solubility of sulphur in $\mathrm{CO}_{2}$ were measured. Isotherm data of the solubility of sulphur at $333.15 \mathrm{~K}$ are measured with pressures ranged from 2.07 MPa to 29.45 MPa. Isotherm data of the solubility of sulphur at $363.15 \mathrm{~K}$ are measured with pressures ranged from $0.93 \mathrm{MPa}$ to $29.27 \mathrm{MPa}$.

\section{REFERENCES}

[1] P.Cézac P., J.-P. Serin, J.-M. Reneaume, J. Mercadier, G. Mouton, J. Supercritical Fluids, vol. 44, 2, 2008, p. 115

[2] H. T. Kennedy, D. R. Wieland, Petroleum Transaction AIME, vol. 219, 1960, p. 166

[3] J. G. Roof, Soc. Petrol. Eng. J., vol.11, 1971, p. 272

[4] E. Brunner, W. Woll, Soc. Petrol.Eng. J., vol.20, 1980, p. 377

[5] E. Brunner, M. Place, W. Woll, Journal of Petroleum Technology, 1988, p. 1587

[6] M-X. Gu, Q. Li, S-Y. Zhou, W-D. Chen, T-M. Guo, Fluid Phase Equilib., vol. 82, 1993, p. 173

[7] C.-Y. Sun, G.-J.Chen, Fluid Phase Equilib., vol. 214, 2003, p. 187

[8] P. D. Bartlett, G. Mergurian G., J. Am. Chem. Soc., vol. 78, 1956, p. 3710

[9] K.L. Lesage, P.D. Clark, J. Chrom. Sci., vol. 27, 1989, p. 259

[10] P.M. Davis, K.L. Lesage, P. D. Clarck, Conference on Natural Gas Odorization, Quality \& Energy Measurement, Chicago IL, 1999 